\title{
Evaluation of the anticancer effects of Aloe vera and aloe emodin on B16F10 murine melanoma and NIH3T3 mouse embryogenic fibroblast cells
}

\author{
Eda Çandöken 1,*, Serap Erdem Kuruca², Nuriye Akev ${ }^{1}$ \\ 'Department of Biochemistry, Faculty of Pharmacy, İstanbul University, 34116, İstanbul, Turkey \\ ${ }^{2}$ Department of Physiology, İstanbul Faculty of Medicine, İstanbul University, 34116, İstanbul, Turkey
}

Cite this article as: Çandöken E, Erdem Kuruca S, Akev N (2017). Evaluation of the anticancer effects of Aloe vera and aloe emodin on B16F10 murine melanoma and NIH3T3 mouse embryogenic fibroblast cells. Istanbul J Pharm 47 (3): 77-83.

\begin{abstract}
Aloe vera (L.) Burm. f. is well known for its beneficial effects on the skin. Moreover, the antioxidant, immunostimulant, and anticancer effects of the plant leaf extracts have been reported in scientific research. This study was conducted to demonstrate the cytotoxic effects of several leaf extracts and aloe emodin (AE) on a type of skin cancer. A. vera aqueous and methanolic extracts of fresh leaves, methanolic extract of dried leaves, and leaf gel extract (AVG) were prepared separately. Cytotoxicity was assessed using the MTT test. Apoptosis and necrosis were detected by flow cytometry using Annexin V/PI. All the extracts exhibited a selective cytotoxic effect on the cells. The mechanism of AVG cytotoxicity on B16F10 murine melanoma cells was found to be apoptosis, whereas that of AE was necrosis. The observation that treatment with AVG delayed the apoptosis in NIH3T3 cells, while it exerted an apoptotic activity on B16F10 cells, provides some scientific evidence for the folkloric and alternative uses of A. vera gel as a protective and skin healer. Therefore, $A$. vera gel and aloe emodin can be used as potential targets for anticancer drug research.
\end{abstract}

Keywords: Aloe vera, aloe gel, aloe emodin, melanoma, cytotoxicity

\section{INTRODUCTION}

Known for centuries as a"wonder" plant, Aloe vera (L.) Burm. f. has many biological and pharmacological activities. These effects are due to the variety of the chemical compounds including anthraquinones, glycoproteins, polysaccharides, vitamins and enzymes contained (Choi and Chung 2003; Du Plessis and Hamman 2014; Akev et al. 2015; Shrestha et al. 2015). Many of the medicinal effects have also been attributed to the immunomodulatory properties of the inner gel (Im et al. 2010), but it is also believed that synergistic action of the compounds contained in the whole leaf extracts is responsible for the multiple and diverse beneficial properties of the plant (Eshun and He 2004).

The mucilageneous gel part of $A$. vera is used commercially as a softener in various cosmetic preparations, soaps and shampoos due to its glycoprotein content. The first known effects of $A$. vera after its cathartic activity, is the wound and burn healing effect of the leaves gel portion, widely supported in scientific literature (Capasso et al. 1998; Chithra et al. 1998; Heggers et al. 1995). Because of this effect, the gel is also added to many preparations used for skin treatment.

Antitumor and cytotoxic potential of A. vera extracts continues to be the interest of scientific research from 1980's (Winters et al. 1981; Tsuda et al. 1993; Corsi et al. 1998) until recent years (Naveena Bharath and Selvasubramanian 2011; Du Plessis and Hamman 2014). In a research undertaken in our laboratory, A. vera leaf skin aqueous extract was proved to be effective as prophylactic against Ehrlich ascites tumours in vivo (Akev et al. 2007). The Food and Drug Administration of the USA has approved the developmental study of A. vera for the treatment of cancer and AIDS (Nandal and Bhardwaj 2012).

Antitumor effect of aloe emodin (AE), the major anthraquinone derivative of $A$. vera, was reported in recent years (Cárdenas et al. 2006; Lee et al. 2006; Lin et al. 2006) and attention has been given recently to the possibility of utilizing AE as a chemothera- 
peutic drug (Chiu et al. 2009; Tabolacci et al. 2010; Mahbub et al. 2013)

The aim of this study was to determine the cytotoxic and apoptotic/necrotic activity of various types of $A$. vera leaf extracts and $A E$ in a type of skin cancer, B16F10 murine melanoma relative to normal fibroblast cell line (NIH3T3 mouse embryogenic fibroblast cells) and to investigate the underlying mechanisms. Cell viability was assessed by trypan blue and cytotoxicity experiments were done using [3-(4,5-dimethylthiazol-2-yl)-2,5-diphenyltetrazolium bromide] (MTT) assay. A. vera extracts and AE and as positive control Imatinib (IM) were tested at different concentrations. Apoptosis and necrosis induction was monitored by flow cytometry using the Annexin V-FITC/ propidium iodide (PI) kit.

\section{MATERIALS AND METHODS}

\section{Cell lines and cell culture}

B16F10 murine melanoma cells (Department of Pharmacology, Akdeniz University School of Medicine, Antalya) and NIH3T3 mouse embryonic fibroblast cells (Department of Physiology, Istanbul Faculty of Medicine İstanbul University, İstanbul) were cultured in IMDM (Iscove's Modified Dulbecco Medium, Sigma-Aldrich) containing $10 \%$ heated-inactivated fetal bovine serum (Capricorn FBS-12A) with 100,000 U/L penicillin and $100,000 \mu \mathrm{g} / \mathrm{L}$ streptomycin (Gibco 15140-122), at $37^{\circ} \mathrm{C}$, in a humidified atmosphere of $95 \% \mathrm{O}_{2} / 5 \% \mathrm{CO}_{2}$. In order to reach the sufficient cell number for tests, cells were passaged after reaching $80 \%$ monolayer confluency. Cells were harvested gently by $0.25 \%$ trypsin (Merck)/EDTA (Chem Cruz) solution. Cells were sub-cultured every 2 or 3 days.

\section{Plant material}

Specimens of A. vera (L.) Burm. f. (Xanthorraceae; in Turkish Sarisabir) were collected from Kale (Demre) in Antalya (May 1993), identified by Prof. Dr. Nurhayat Sütlüpınar and cultivated since this date in the greenhouses of the Faculty of Pharmacy and further in Istanbul University Alfred Heilbronn Botanical Garden. A voucher specimen was deposited in the Herbarium of the Faculty of Pharmacy, ISTE No. 65118. The fresh leaves of this cultivated plant were used in the study.

\section{Preparation of extracts}

Four types of extract were prepared separately from $A$. vera leaves: Aqueous extract of fresh leaves, gel extract (AVG), methanol extract of fresh leaves and methanol extract of dried leaves.

\section{Preparation of aqueous extract of fresh leaves and gel extracts}

Freshly chopped A. vera leaves, were washed carefully with water and dried with filter paper (Whatmann 41) to remove dust and foreign materials. Then the washed leaves were longitudinally split in two, the gel (198.74 g) was separated by scraping with a spoon and homogenized in a Waring blendor. The remaining leaves (leaf skins 171 g) were cut in small pieces, homogenized in a Waring blender with $855 \mathrm{ml}$ distilled water, filtered through cloth and then the filtrate was centrifuged (Thermo) at $+4^{\circ} \mathrm{C}, 12$ $000 \mathrm{rpm}, 15 \mathrm{~min}$. The supernatant was lyophylized (11.57 g) and considered to be $A$. vera aqueous extract of fresh leaves. The gel was filtered through cloth and then filtrate was centrifuged at $+4^{\circ} \mathrm{C}, 10000 \mathrm{rpm}$, for $30 \mathrm{~min}$. The supernatant was lyophylized $(4.63 \mathrm{~g})$ and considered to be $A$. vera gel extract (AVG).

\section{Preparation of methanolic extracts of fresh leaves and dried leaves}

Fresh leaf skins $\left(33.67 \mathrm{~g}\right.$ ) were dried in ventilated oven at $60^{\circ} \mathrm{C}$, $2 \mathrm{~h}$. The dried samples were then ground to obtain powder which was stored at room temperature in the dark until extraction. The obtained dried leaf skin $(4.25 \mathrm{~g})$ and fresh leaf skin (73.4 g) were extracted separately with methanol for 3 days using Soxhlet extractor until complete extraction. After extraction, the samples were filtered with filter paper (fresh leaves filtrate $260 \mathrm{ml}$, dried leaves filtrate $143 \mathrm{~mL}$ ). The methanol solvent was evaporated using a rotary evaporator under pressure for 30 min resulting in a semi solid crude extract and considered to be (3.32 g) A. vera methanol extract of fresh leaves. The same procedure was performed after drying leaf skins at $60^{\circ} \mathrm{C}$ for $2 \mathrm{~h}$ in an oven and considered to be $(1.17 \mathrm{~g})$ A. vera methanol extract of dried leaves.

These four different extracts prepared as described above were conserved at $-20^{\circ} \mathrm{C}$ until further use.

\section{Preparation of test materials and reference drugs}

AE (1,8-dihydroxy-3-[hydroximethyl]-anthraquinone) was purchased from Sigma-Aldrich (St Louis, MO, cat no. A7687). A. vera extracts $(10 \mathrm{mg} / \mathrm{mL})$ and $A E(20 \mathrm{mM})$ stock solutions were prepared in dimethyl sulfoxide (DMSO was spurchased from Sigma-Aldrich, D2650), aliquoted and stored in the dark at $-20^{\circ} \mathrm{C}$ till use, then diluted with medium. The reference chemotherapeutic drug Imatinib (IM) was purchased from Santa Cruz, 10 mM stock solution was prepared in DMSO; aliquoted and stored in the dark at $-20^{\circ} \mathrm{C}$ till use, then diluted with medium (see below); the final concentration of DMSO in medium was less than $1 \%(\mathrm{v} / \mathrm{v})$.

\section{Trypan blue exclusion assay}

The total number of viable cells was determined at each time point by the trypan blue exclusion test (Strober 2001). Exactly $10 \mu \mathrm{l}$ of cell suspensions were stained with an equal volume of trypan blue [0.4\% in $10 \mathrm{mM}$ in phosphate buffer saline (PBS)] for $1 \mathrm{~min}$. Then the numbers of viable cells were counted with Neubauer Chamber by light microscopy (Olympus). Cells that retained a blue colour were considered as dead cells.

\section{MTT colorimetric assay}

The 3-(4,5-dimethylthiazol-2-yl)-2,5-diphenyltetrazolium bromide (MTT) colorimetric assay was used to screen for cytotoxic activity (Mosmann 1983). For this purpose 96-well plates were used and the assay was done in a total volume of $100 \mu$ l. Briefly, $10 \mu \mathrm{l} /$ well of varying concentrations of $A$. vera extracts and as positive controls: IM $(0.5-100 \mu \mathrm{M})$ and $\mathrm{AE}(10-100 \mu \mathrm{M})$ were added and subsequently the cells $\left(90 \mu \mathrm{l} / \mathrm{well} ; 10^{5}\right.$ cells $/ \mathrm{mL}$ culture medium) were seeded to treat for $72 \mathrm{~h}$. In addition, 90 $\mu \mathrm{l}$ cell suspension and $10 \mu \mathrm{l}$ medium were added to control wells. After the aspiration of the supernatant ( $50 \mu \mathrm{l} /$ well), and subsequent incubation with MTT (Sigma-Aldrich) solution (10 $\mu \mathrm{l}$ of $5 \mathrm{mg} / \mathrm{mL} \mathrm{PBS}$ ) at $37^{\circ} \mathrm{C}$ for $3 \mathrm{~h}$, cells were lyzed with 100 
Çandöken et al. Evaluation of the anticancer effects of Aloe vera and aloe emodin on B16F10 murine melanoma and NIH3T3 mouse embryogenic fibroblast cells

$\mu$ I DMSO. Absorbance was measured at $570 \mathrm{~nm}$ using a ELISA microplate reader (Rayto RT-2100C). The percentage of viable cells $(\mathrm{VI})$ determined with the equation (1):

$\mathrm{VI}=($ Absorbance of the treated cells $\div$ Absorbance of the control cells) $\times 100(1)$

The cytotoxic concentrations of extracts that provides 50\% inhibition of cell growth $\left(\mathrm{IC}_{50}\right)$ were calculated from a dose-response curve. The cytotoxic effect of $A$. vera extracts and controls were evaluated by comparing the $I C_{50}$ values of cell lines.

\section{Flow cytometry analysis}

Normal, apoptotic, and necrotic cells were distinguished using an Annexin V-FITC/PI assay kit (Millipore) according to the manufacturer's instructions. For this purpose a 6-well plate was used and the assay was done in a total volume of $2 \mathrm{~mL}$. The three groups of cells (two untreated control cells group: to apply and unapplied Annexin V-FITC/PI for one test group; $1800 \mu \mathrm{l} /$ well; $10^{5}$ cells $/ \mathrm{mL}$ culture medium) were seeded in a final concentration of IC 50 (200 $\mu \mathrm{l} /$ well) of AVG and AE. Subsequent to culture at $37^{\circ} \mathrm{C}$ with $5 \% \mathrm{CO}_{2}$ for $72 \mathrm{~h}$, the cells were harvested by trypsinization. Trypsinized and loose cells were then combined and pelleted by centrifuging at $2000 \mathrm{rpm}$ for $10 \mathrm{~min}$. The pellets were resuspended and washed with PBS, then resuspended in $100 \mu \mathrm{l}$ of Annexin Binding Buffer (4X) and stained with $3 \mu$ Annexin V-FITC, $2 \mu \mathrm{lPI}$. The cell suspension was incubated for $45 \mathrm{~min}$ at room temperature in the dark. The cell suspension was then immediately analyzed by flow cytometry. Cell Quest software was used to analyze $10^{4}$ cells. Acquisition of samples were determined with a FACS Calibur flow cytometer and analyzed with CELLQUEST software (BD Biosciences).

\section{Statistical Analysis}

The results were statistically analyzed using the independent Student's t-test. Data were represented as means \pm standard deviation (S.D.) and at least in triplicate. Results were considered significant with $p<0.05\left(^{*}\right), p<0.01\left(^{* *}\right)$ and $\mathrm{p}<0.001{ }^{(* * *)}$.

\section{RESULTS}

Among the four extracts studied, aqueous extract of fresh leaves and AVG has been shown to have selective cytotoxic effect on B16F10 cells in comparison to NIH3T3 cells with a higher $I C_{50}$ level in the same concentrations. Cytotoxic effect of both methanol-extracts was lower than that of aqueous extract and AVG (Table 1).
In vitro cytotoxic effects of $A$. vera extracts $(62.5,125,250 \mu \mathrm{g} /$ $\mathrm{mL}$ ) on B16F10 murine melanoma cells in vitro was as follows in decreasing order: aqueous extract of fresh leaves $>$ AVG $>$ methanol extract of dried leaves $>$ methanol extract of fresh leaves (Figure 1a). No data on the $\mathrm{IC}_{50}$ value of IM for the B16F10 murine melanoma cells was found in the literature. In our study, IM was more cytotoxic to NIH3T3 cells in comparison to

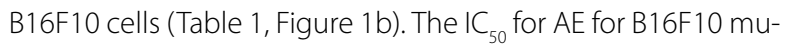
rine melanoma cells was reported to be $60 \mu \mathrm{M}$ (Tabolacci et al. 2010). In our study, similarly, the $I C_{50}$ value for B16F10 murine melanoma cells of AE was found to be $68.48 \pm 9.85 \mu \mathrm{M}$ (Figure 1c). AE was found to be more effective in B16F10 cells than IM $(120 \pm 7.41)$ (Table 1).

In vitro cytotoxic effects of $A$. vera extracts (100, 200, 300 $\mu \mathrm{g} / \mathrm{mL}$ ) on NIH3T3 mouse embryonic fibroblast cells in vitro was as follows in decreasing order: methanol extract of dried leaves $>$ AVG > methanol extract of fresh leaves $>$ aqueous extract of fresh leaves (Figure 2a). No data on the $\mathrm{IC}_{50}$ value of IM for NIH3T3 mouse embryonic fibroblast cells was found in the literature. In our study, the $\mathrm{IC}_{50}$ value of IM for NIH3T3 cells was found to be $100 \pm 2.11 \mu \mathrm{M}$ (Table 1, Figure 2b). Either, no work on the in vitro cytotoxic effect of AE on NIH3T3 cells was found. In our study, the $I_{50}$ value for $\mathrm{AE}$ on $\mathrm{NIH} 3 \mathrm{~T} 3$ mouse embryonic fibroblast cells was 36.68 $\pm 1.83 \mu \mathrm{M}$ (Figure 2c).

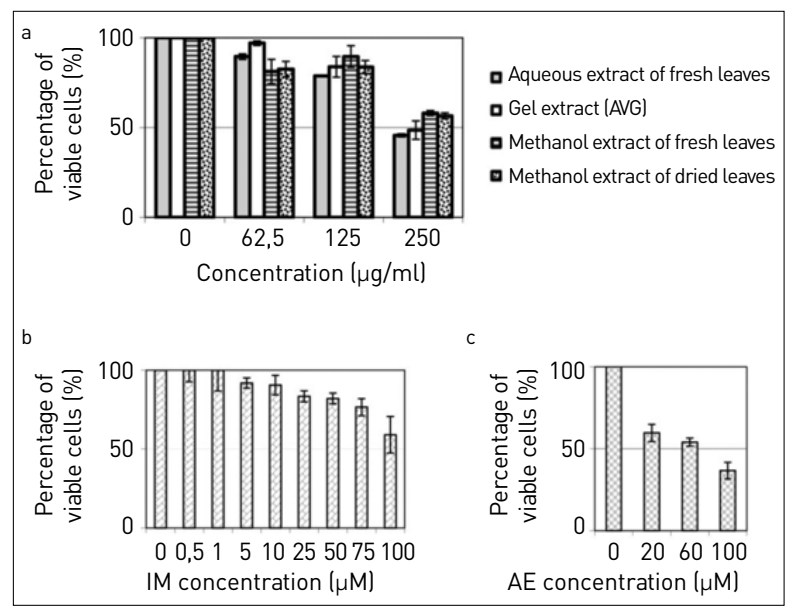

Figure 1. a-c. The cytotoxic effects of (a) $A$. vera extracts, (b) Imatinib and (c) Aloe emodin on B16F10 cell line. Data are presented as the mean of three replicates \pm standard deviation (S.D.). IM: Imatinib; AE: aloe emodin

Table 1. IC ${ }_{50}$ values of $\boldsymbol{A}$. vera extracts, IM and AE for cell lines.

\begin{tabular}{|c|c|c|c|c|c|c|}
\hline \multicolumn{7}{|c|}{ IC50* \pm S.D. } \\
\hline Cells & $\begin{array}{l}\text { Aqueous extract of fresh } \\
\text { leaves }(\mu \mathrm{g} / \mathrm{mL})\end{array}$ & $\begin{array}{c}(\mathrm{AVG}) \\
(\mu \mathrm{g} / \mathrm{mL})\end{array}$ & $\begin{array}{l}\text { Methanol extract of fresh } \\
\text { leaves }(\mu \mathrm{g} / \mathrm{mL})\end{array}$ & $\begin{array}{c}\text { Methanol extract of dried } \\
\text { leaves }(\mu \mathrm{g} / \mathrm{mL})\end{array}$ & $\underset{(\mu \mathrm{M})}{\mathrm{IM}}$ & $\begin{array}{c}\mathrm{AE} \\
(\mu \mathrm{M})\end{array}$ \\
\hline B16F10 & $239.26 \pm 3.68$ & $259.79 \pm 25.65$ & $321.04 \pm 9.57$ & $297.98 \pm 11.33$ & $120 \pm 7.41$ & $68.48 \pm 9.85$ \\
\hline NIH3T3 & $313.13 \pm 15$ & $285.50 \pm 15.51$ & $300.07 \pm 17.26$ & $274.27 \pm 19.75$ & $100 \pm 2.11$ & $36.68 \pm 1.83$ \\
\hline
\end{tabular}


Apoptosis/necrosis studies with flow cytometry were undertaken with AVG and AE in order to elucidate the mechanism of the cytotoxic activity.

As seen in Figure 3a, the control group B16F10 murine melanoma cells showed $7.59 \%$ early apoptosis, $1.55 \%$ late apoptosis and $5.04 \%$ necrosis. Early and late apoptosis rates in B16F10 murine melanoma cells treated with AVG were $13.98 \%$ and $22.40 \%$, respectively, while necrosis rate was $2.22 \%$.

As shown in Figure 3b, early and late apoptosis rates in B16F10 murine melanoma cells treated with AE were $2.81 \%$ and $0.39 \%$ respectively, while necrosis rate was $21.25 \%$.

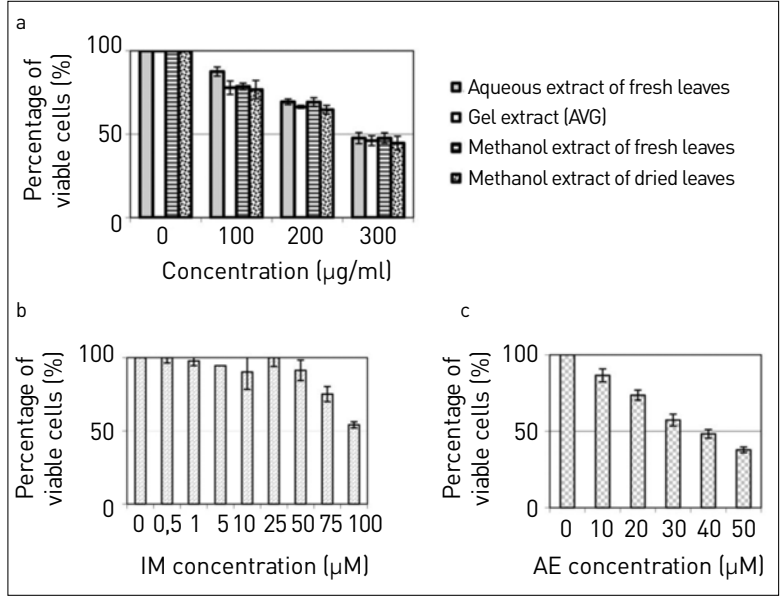

Figure 2. a-c. The cytotoxic effects of (a) $A$. vera extracts, (b) Imatinib and (c) Aloe emodin on NIH3T3 cell line. IM: Imatinib; $A E$ : aloe emodin
For NIH3T3 mouse embryonic fibroblast cells treated with AVG, the control group showed $26.30 \%$ early apoptotic and $21.63 \%$ late apoptotic cell ratio. It is an important finding that, treatement of NIH3T3 mouse embryonic fibroblast cells with AVG retract the dead cell ratio to $8.49 \%$ and $19.66 \%$ (Figure $4 a, b$ ).

The dose dependent and selective cytotoxic effect of AVG treatment on B16F10 murine melanoma cells compared to NIH3T3 mouse embryonic fibroblast cells were also proved by the microscopic visualization (Figure 5a, b).

\section{DISCUSSION}

A. vera is often called the "Natural healer". Aloe gel is excellent for healing burns, releives inflammation and accelerates healing (Nandal and Bhardwaj 2012). It has also been demonstrated that the plant has a prophylactic effect if used before, during and after skin damaging events. The polysaccharides, mannose-6-phosphate and complex anthroquinones all contribute synergistically to the benefits of the plant (Dweck 2002).

Skin cancer is an increasing threat to humans because exposure to chemical carcinogens as well as UV irradiation increases day by day in the modern world. Studies about the anticancer effect of $A$. vera gel and leaf extracts have been undertaken on different cancer types in vivo (Corsi et al. 1998; Akev et al. 2007; Naveena Bharath and Selvasubramanian 2011) and cell lines in vitro (Al-Oqail et al. 2016). In another study, it was stated that $A$. vera protects mice against DMBA/croton oil induced skin papillomagenesis (Saini et al. 2010). Literature on the effect of aloe extracts on skin cancer are scarce. Only one study was found on the effect of $A$. vera extract on B16F10 melanoma

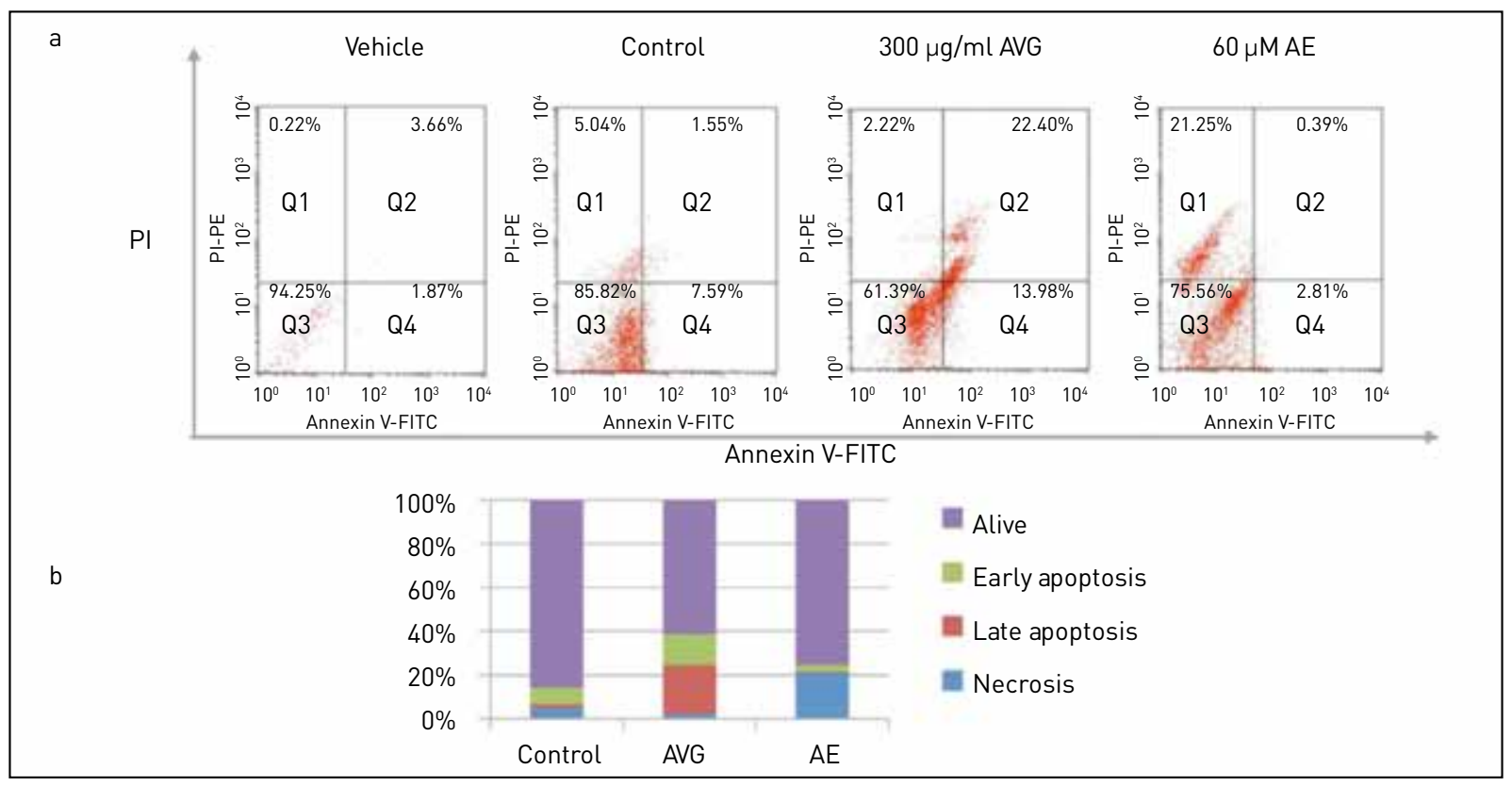

Figure 3. a, b. (a) Flow Cytometry of B16F10 cells treated with Annexin V-FITC/PI. Vehicle: Control cells without the presence of Annexin V-FITC /PI. Control: Cells without the presence of $A$. vera gel extract (AVG) and aloe emodin (AE). The cells were incubated with $A$. vera gel extract $(300 \mu \mathrm{g} / \mathrm{ml})$ and $\mathrm{AE}(60 \mu \mathrm{M})$ for $72 \mathrm{~h}$, stained with Annexin V-FITC /PI and analyzed by FACScan flow cytometer marked for apoptosis/necrosis. Q1: Annexin V negative/PI positive; Q2: Annexin V/PI positive; Q3: Annexin V positive/ PI negative; Q4: Annexin V/PI negative.The analysis of data from flow Cytometry was performed using the FlowJo software. (b) Histogram representation of the quantitative percentage of alive, early, late and necrotic cell populations 
Çandöken et al. Evaluation of the anticancer effects of Aloe vera and aloe emodin on B16F10 murine melanoma and NIH3T3 mouse embryogenic fibroblast cells

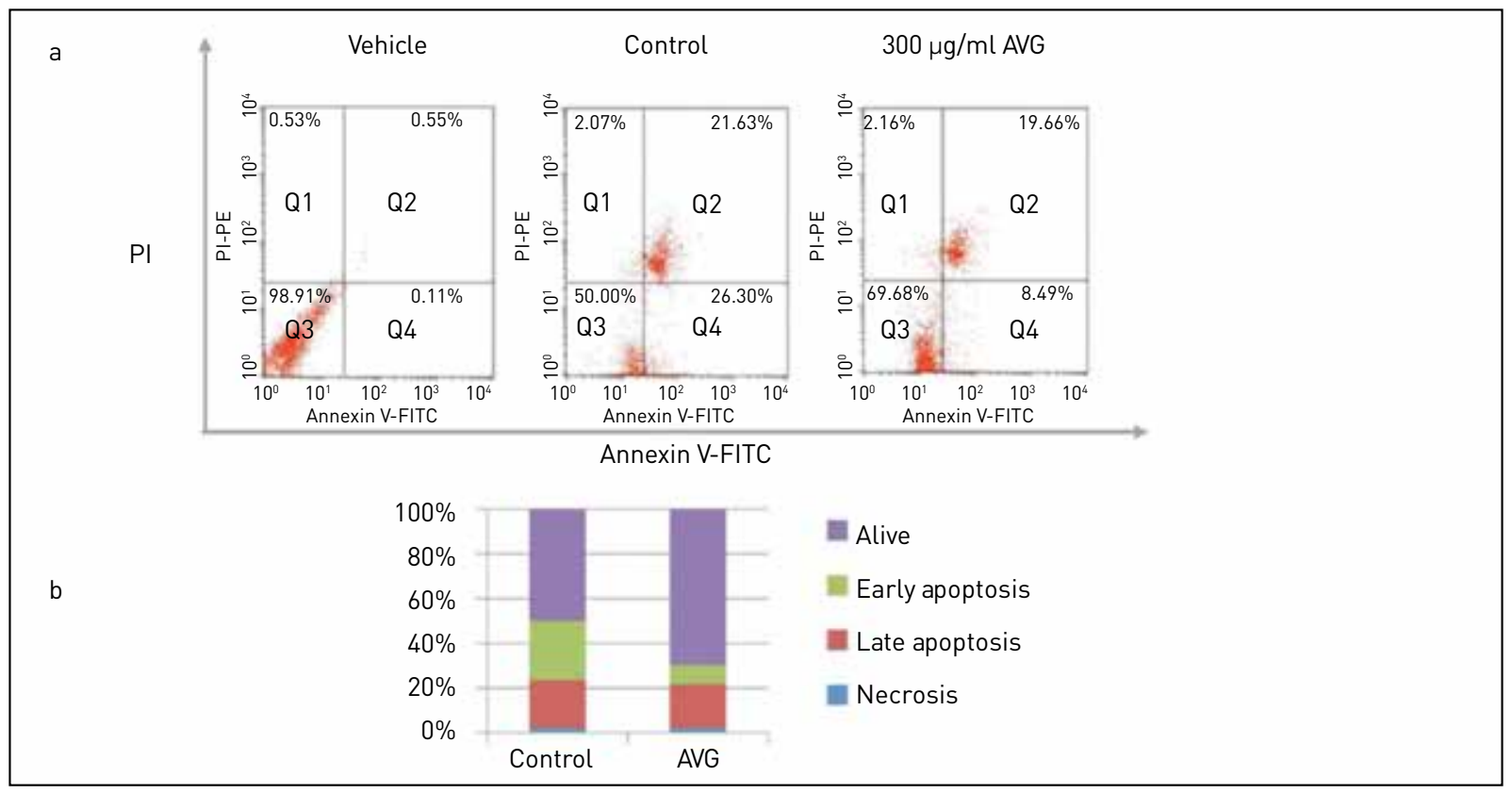

Figure 4. a, b. (a) Flow Cytometry of NIH3T3 cells treated with Annexin V-FITC/PI. Vehicle: Control cells without the presence of Annexin V-FITC /PI. Control: Cells without the presence of A. vera gel extract (AVG). The cells were incubated with A. vera gel extract $(300 \mu \mathrm{g} / \mathrm{ml})$ for $72 \mathrm{~h}$, stained with Annexin V-FITC /PI and analyzed by FACScan flow cytometer marked for apoptosis/necrosis. Q1: Annexin V negative/PI positive; Q2: Annexin V/PI positive; Q3: Annexin V positive/PI negative; Q4: Annexin V/PI negative. The analysis of data from flow Cytometry was performed using the Flow Jo software. (b) Histogram representation of the quantitative percentage of alive, early, late and necrotic cell populations.

a
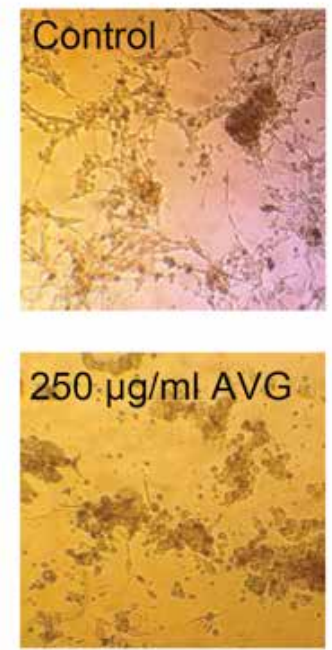
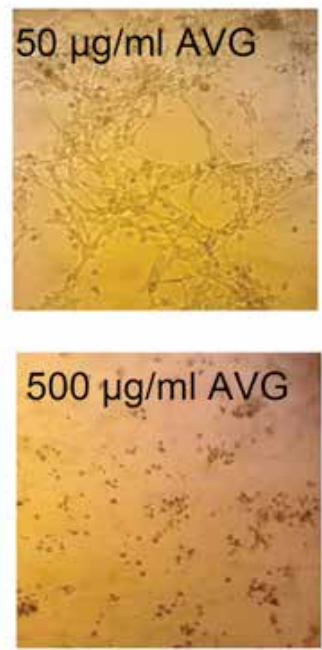

b
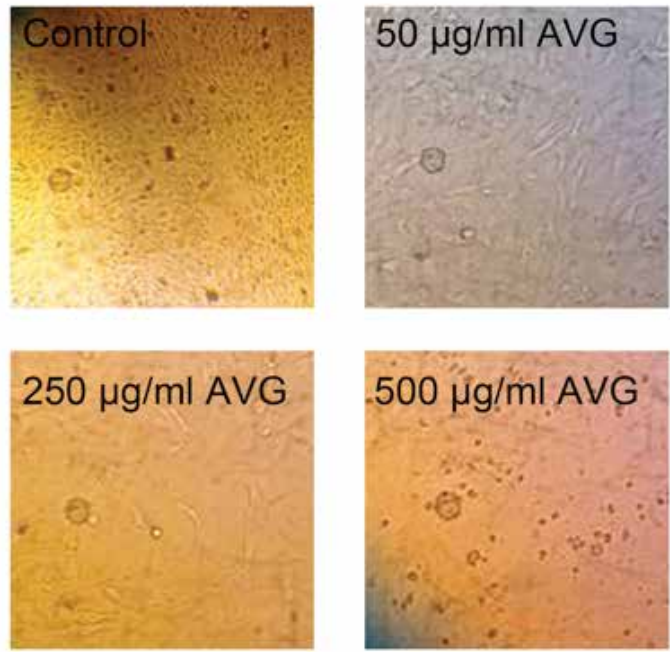

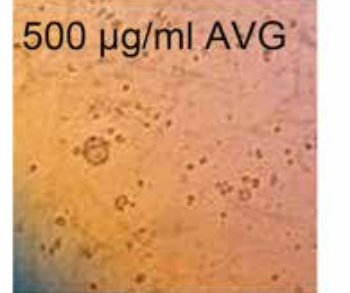

Figure 5. a, b. Visualization of (a) B16F10 and (b) NIH3T3 cells using inverted microscope after treatment with $A$. vera gel extract (AVG: 50,250 and $500 \mu \mathrm{g} / \mathrm{mL}$ )

cells (Chandu et al. 2012). To our knowledge, this is the first study dealing with the mechanism of AVG and AE cytotoxicity. In this study, the mechanism of AVG cytotoxicity on B16F10 murine melanoma cells was found to be related to apaptosis while that of AE was necrosis. On the other hand, we can say that, in NIH3T3 mouse embryonic fibroblast cells, treatment with AVG, increased the percentage of viable cells by delaying apoptosis. This result could be considered in accordance with the use of aloe gel in cosmetics and in alternative medicine for centuries as a preservative or antiaging product. We can also suggest that the anticancer effect of aloe gel is better than that of the purified substance AE in terms of apoptotic/ necrotic mechanims.

Aloe emodin, one of the main constituents of the plant, is in turn suggested as a novel anticancer drug (Ahirwar and Jain 2011; Yordanova and Koprinarova 2014). In terms of skin cancer, AE significantly stopped the proliferation process of irradiated keratinocytes (human skin cells). This confirmed Aloe's benefit in halting the progression of tumor formation after radiation 
by the sun (Popadic et al. 2012). The apoptotic effect of AE was demonstrated in T24 human bladder cancer cells through the p53 dependent apoptotic pathway (Lin et al. 2006) and also in human gastric carcinoma cells (Chen et al. 2007). In our study, the $\mathrm{IC}_{50}$ value for B16F10 murine melanoma cells of AE was found to be $68.48 \pm 9.85 \mu \mathrm{M}$ similarily to the results of (Tabolacci et al. 2010) which was reported to be $60 \mu \mathrm{M}$.

The well documented immunostimulant effect of the plant leaf extracts (Im et al. 2010; Srivastava et al. 2014) as well as their antioxidant activity (Ozsoy et al. 2009) could also have had an influence on the selective cytotoxic effectiveness.

\section{CONCLUSION}

The benefits of $A$. vera extracts and aloe derivatives on skin as well as their demonstrated anticancer properties, makes the plant a good target for studies on skin related diseases and skin cancer. We have demonstrated in the present study the cytotoxic effect of A. vera extracts and AE and their apototic/ necrotic mechanisms, on a skin cancer cell type. No difference was observed between the cytotoxic effects of aqueous and methanolic extracts as well extracts obtained from fresh or dried leaves. A. vera gel and AE are thus potential targets for anticancer drug research.

\section{Acknowledgement}

This work was supported by Istanbul University Scientific Research Projects. Project Number: 28775. The authors wish to thank Doç. Dr. Nuray Erin from Akdeniz University, Faculty of Medicine, Department of Pharmacology, for the kind gift of B16F10 murine melanoma cells and PhD. Sema Bilgiç Gazioğlu from Istanbul University, Aziz Sancar Institute of Experimental Medicine, Department of Immunology, for technical help during flow cytometry analysis.

\section{REFERENCES}

- $\quad$ Ahirwar K, Jain SK (2011). Aloe-emodin novel anticancer herbal drug. Int J Phytomed 3: 27-31.

- Akev N, Can A, Sütlüpınar N, Çandöken E, Özsoy N, Yılmaz Özden T, Yanardağ R, Üzen E (2015). Twenty years of research on Aloe vera. J Fac Pharm Istanbul 45: 191-215.

- Akev N, Turkay G, Can A, Gurel A, Yildiz F, Yardibi H, Ergul Ekiz E, Uzun $H$ (2007). Effect of Aloe vera leaf pulp extract on Ehrlich ascites tumours in mice. Eur J Cancer Prev 16: 151-157. [CrossRef]

- Al-Oqail MM, El-Shaibany A, Al-Jassas E, Al-Sheddi ES, Al-Massarani SM, Farshori NN (2016). In vitro anti-proliferative activities of Aloe perryi flowers extract on human liver, colon, breast, lung, prostate and epithelial cancer cell lines. Pak J Pharm Sci 29(2 Suppl.): 723-729.

- Capasso F, Borrelli F, Capasso R, Di Carlo G, Izzo AA, Pinto L et al. (1998). Aloe and its therapeutic use. Phytother Res 12: 124-127. [CrossRef]

- Cárdenas C, Quesada AR, Medina MA (2006). Evaluation of the anti-angiogenic effect of aloe-emodin. Cell Mol Life Sci 63: 30833089. [CrossRef]

- Chandu AN, Kumar SC, Bhattacharjee C, Debnath S (2012). Cytotoxicity study of plant Aloe vera (Linn). Chronicles of Young Scientists 3: 233-235. [CrossRef]
Chen S-H, Lin K-Y, Chang C-C, Fang C-L, Lin C-P (2007). Aloe-emodin-induced apoptosis in human gastric carcinoma cells. Food Chem Toxico/ 45: 2296-2303. [CrossRef]

- Choi S, Chung M-H (2003). A review on the relationship between Aloe vera components and their biologic effects. Sem Integr Med 1: 53-62. [CrossRef]

- Chithra P, Sajithlal GB, Chandrakasan G (1998). Influence of Aloe vera on the glycosaminoglycans in the matrix of healing dermal wounds in rats. J Ethnopharmacol 59: 179-186. [CrossRef]

- $\quad$ Chiu T-H, Lai W-W, Hsia T-C, Yang J-S, Lai T-Y, Wu P-P, Ma C-Y, Yeh C-C, Ho C-C, Lu H-F, Gibson Wood W, Chung J-G (2009). Aloeemodin induces cell death through S-phase arrest and caspasedependent pathways in human tongue squamous cancer SCC-4 cells. Anticancer Res 29: 4503-4512.

- Corsi MM, Bertelli AA, Gaja G, Fulgenzi A, Ferrero M.E (1998). The therapeutic potential of Aloe vera in tumor-bearing rats. Int J Tissue React 20: 115-118.

- Dweck AC (2002). Herbal Medicine for the skin - their chemistry and effects on the skin and mucous membranes. Personal Care Magazine 3, 2: 19-21

- Du Plessis LH, Hamman JH (2014). In vitro evaluation of the cytotoxic and apoptogenic properties of aloe whole leaf and gel materials. Drug Chem Toxico/ 37:169-177. [CrossRef]

- Eshun K, He Q (2004). Aloe vera: a valuable ingredient for the food, pharmaceutical and cosmetic industries-a review. Crit Rev Food Sci Nutr 44: 91-96. [CrossRef]

- Heggers JP, Kucukcelebi A, Stabenau, CJ, Ko F, Broemeling LD, Robson MC, Winters WD (1995). Wound healing effects of Aloe gel and other topical antibacterial agents on rat skin. Phytother Res 9: 455-457. [CrossRef]

- Im S-A, Lee Y-R, Lee Y-H, Lee M-K, Park Yl. Lee S et al (2010). In vivo evidence of the immunomodulatory activity of orally administered Aloe vera gel. Arch Pharm Res 33: 451-456. [CrossRef]

- $\quad$ Lee H-Z, Lin C-J, Yang W-H, Leung W-C, Chang S-P (2006). Aloe emodin induced DNA damage through generation of reactive oxygen species in human lung carcinoma cells. Cancer Lett 239: 55-63. [CrossRef]

- $\quad$ Lin JG, Chen G, Li TM, Chouh ST, Tan TW, Chung G (2006). Aloeemodin induces apoptosis in T24 human bladder cancer cells through the 553 dependent apoptotic pathway. J Uro/ 175: 343347. [CrossRef]

Mahbub AA, Le Maitre CL, Haywood-Small SL, McDougall GJ, Cross N., Jordan-Mahy N (2013). Differential effects of polyphenols on proliferation and apoptosis in human myeloid and lymphoid leukemia cell lines. Anti-Cancer Agents in Medicinal Chemistry 13: 1601-1613. [CrossRef]

Mosmann T (1983). Rapid colorimetric assay for cellular growth and survival: application to proliferation and cytotoxicity assays. J Immunol Methods 65: 55-63. [CrossRef]

- Nandal U, Bhardwaj RL (2012). Aloe vera for human nutrition, health and cosmetic use-A review. International Research Journal of Plant Science 3: 38-46.

- Naveena Bharath BK, Selvasubramanian (2011). Antitumor activity of Aloe vera against Ehrlich ascitis carcinoma (EAC) in swiss albino mice. Int J Pharma Bio Sci 2: P400-P408.

- $\quad$ Ozsoy N, Candoken E, Akev N (2009). Implications for degenerative disorders. Antioxidative activity, total phenols, flavonoids, ascorbic acid, $\beta$-carotene, $a$ - tocopherol in Aloevera. Oxid Med Cell Longev 2: 1-8. [CrossRef]

Popadic D, Savic E, Ramic Z, Djordjevic V, Trajkovic V, Medenica L, Popadic S (2012). Aloe-emodin inhibits proliferation of adult human keratinocytes in vitro. J Cosmet Sci 63: 297-302. 
Çandöken et al. Evaluation of the anticancer effects of Aloe vera and aloe emodin on B16F10 murine melanoma and NIH3T3 mouse embryogenic fibroblast cells

- $\quad$ Saini M, Goyal PK, Chaudhary G (2010). Anti-tumor activity of Aloe vera against $\mathrm{DMBA}$ /croton oil-induced skin papillomagenesis in Swiss albino mice. J Environ Pathol Toxicol Oncol 29: 127-35. [CrossRef]

- Shrestha A, Acharya A, Nagalakshmi NC (2015). Aloe vera as traditional medicinal plant: a review on its active constituents, biological and therapeutic effects. World J Pharm Res 4: 21462161.

- $\quad$ Srivastava R, Jyoti B, Pathak S, Wazir SS, Shukla A, Sajid Z (2014). Aloe vera: The herbal magic wand. J Clin Den Res Edu 3

- Strober W (2001). Trypan blue exclusion test of cell viability. Curr Protoc Immunol Appendix 3: Appendix 3B. doi: 10.1002/0471142735.ima03bs21. [CrossRef]
Tabolacci C, Lentini A, Mattioli P, Provenzano B, Oliverio S, Carlomosti F, Beninati S (2010). Antitumor properties of aloe-emodin and induction of transglutaminase 2 activity in B16-F10 melanoma cells. Life Sci 87: 316-324. [CrossRef]

- Tsuda H, Matsumoto K, Ito M, Hirono I, Kawai K, Beppu H et al. (1993). Inhibitory effect of Aloe arborescens Miller var. nataliensis Berger (Kidachi aloe) on induction of preneoplastic focal lesions in the rat liver. Phtother Res 7: S43-S47. [CrossRef]

Winters WD, Benavides R, Clouse,WJ (1981). Effects of Aloe extracts on human normal and tumor cells in vitro. Econ Bot 35: 89-95. [CrossRef]

Yordanova A, Koprinarova M (2014). Is aloe-emodin a novel anticancer drug? Trakia Journal of Sciences 12, Suppl. 1: 92-95. 